\title{
Influence of the content of vitamin C in secretion from sows' mammary glands on piglet rearing
}

\author{
EWA SKRZYPCZAK, MAREK BABICZ*, GRAŻYNA CZYŻAK-RUNOWSKA, \\ KAROLINA SZULC, MAGDALENA SZYNDLER-NĘDZA**, \\ IWONA ŁUSZCZEWSKA-SIERAKOWSKA***
}

\author{
Department of Animal Breeding and Product Quality Assessment, Faculty of Veterinary Medicine and Animal Science, \\ Poznań University of Life Sciences, Złotniki, ul. Słoneczna 1, 62-002 Suchy Las, Poland \\ *Institute of Animal Breeding and Biodiversity Protection, Sub-Department of Pig Breeding and Biotechnology, \\ Faculty of Biology, Animal Sciences and Bioeconomy, University of Life Sciences, \\ ul. Akademicka 13, 20-950, Lublin, Poland \\ **Department of Pig Breeding, National Research Institute of Animal Production, \\ ul. Krakowska 1, 32-083 Balice n. Kraków, Poland \\ ***Department of Human Anatomy, Sub-Department of Human Anatomy, \\ Medical University of Lublin, Jaczewskiego 4, 20-090 Lublin, Poland
}

Skrzypczak E., Babicz M., Czyżak-Runowska G., Szulc K., Szyndler-Nędza M., Łuszczewska-Sierakowska I. Influence of the content of vitamin C in secretion from sows' mammary glands on piglet rearing

\section{Summary}

The aim of the study was to assess the endogenic production of vitamin $C$ contained in the sow's colostrum and milk and its influence on piglet rearing parameters. The study was conducted on 60 Zlotnicka White sows and 642 piglets from their litters (366 male and 276 female piglets). The sows were in their $3^{\text {rd }}, 4^{\text {th }}, 6^{\text {th }}$ or $7^{\text {th }}$ lactation. There were 15 sows in each lactation group. The study covered a period of one lactation. The feed of the sows was not supplemented with vitamin C. During the experiment the piglets received only their mothers' milk. The piglets were weighed on the $1^{\text {st }}, 7^{\text {th }}$ and $21^{\text {st }}$ day of life $(\mathrm{kg})$. Their mortality between the $1^{\text {st }}$ and $7^{\text {th }}$ day of life and between the $8^{\text {th }}$ and $21^{\text {st }}$ day of life $(\%)$ was recorded. The daily growth $(\mathrm{g})$ was measured on each day when the piglets were weighed. Samples of colostrum and milk were collected manually from all active mammary glands on the $1^{\text {st }}, 7^{\text {th }}$ and $21^{\text {st }}$ day of lactation. On each day of the experiment, two samples of about $7 \mathrm{ml}$ were collected from each sow. A total of 360 samples were analysed (60 sows $\times 3$ days $\times 2$ samples). In order to verify the influence of vitamin $C$ on piglet rearing, two concentration levels of vitamin $C$ were distinguished according to its content in colostrum and milk (Tab. 1). The research showed that the content of vitamin $C$ varied during lactation. The highest mean concentration of vitamin $C$, i.e. $1.14 \mathrm{mg} / 100 \mathrm{ml}$, was noted on the $1^{\text {st }}$ day. On the $21^{\text {st }}$ day it decreased to $0.65 \mathrm{mg} / 100 \mathrm{ml}$. During 21 days of lactation the content of vitamin $C$ decreased by $\mathbf{4 3} \%$. Sows in their fourth lactation produced colostrum with the highest content of vitamin C, i.e. $1.29 \mathrm{mg} / 100 \mathrm{ml}$. Animals that lactated for the sixth time had the highest content of vitamin $\mathrm{C}$ in their milk, i.e. 0.75 and $0.70 \mathrm{mg} / 100 \mathrm{ml}$, on the $7^{\text {th }}$ and $21^{\text {st }}$ day, respectively. The daily growth of piglets was greater if the content of vitamin $C$ in colostrum and milk collected during rearing was high (level II). On average, the differences amounted to about $68 \mathrm{~g}$. The higher the content of vitamin $\mathrm{C}$ in the secretion from the sows' mammary glands was, the lower the piglet mortality was. Statistically significant $(p \leq 0.01)$ relationships were found between daily growth and the content of vitamin $C$. The higher concentration of vitamin $C$ produced better results in rearing in the form of a faster growth and lower mortality of piglets.

Keywords: vitamin C, sow's milk and colostrum, piglet rearing

All pig breeders and producers want piglets to be strong and healthy and their survival rate to be as high as possible. We know that piglet rearing conditions are influenced by several factors, such as zoohygiene, the health of sows and their lactation yield. All these fac- tors must be favourable for new-born piglets to survive the most difficult period before their organisms develop defence systems. Piglets need energy and nutrients for development. The sow needs to satisfy all nutritional needs of the piglets at this critical time in their lives. 
Vitamins are compounds necessary for normal function of the organism. They are not a source of energy or structural material, but they regulate different functions in cells and tissues that are decisive to the development of the organism. Vitamin C, aka ascorbic acid, is an important micronutrient for normal function of living organisms. It participates in various reactions and biochemical transformations in the organism. Animals are capable of synthesising vitamin C. The liver is an organ where ascorbic acid is synthesised in the organism of mammals, including pigs (3). Animals can generate vitamin $\mathrm{C}$ from glucose by means of L-gulonolactone oxidase (GLO). This enzyme converts gulonolactone into L-ascorbic acid in the uronic acid cycle $(4,9,18,26)$.

Vitamin C, i.e. L-ascorbic acid, has a wide-ranging influence on the immune system. It stimulates the activity and transport of leukocytes. It participates in the production of immunoglobulins, metabolic processes and various significant reactions. It enables the animal to recover from diseases caused by various pathogenic microorganisms (14).

Vitamin C deficiency may cause dysfunction of different systems and thus weaken the organism. Vitamin $\mathrm{C}$ is particularly important for piglets because it affects haematopoietic processes, especially the synthesis of haemoglobin, by maintenance of the divalent form of iron (8). The content of vitamin $\mathrm{C}$ in colostrum and milk is not constant, and it varies at different lactation phases $(6,8)$. Therefore the aim of the study was to determine the content of this vitamin in the secretion from sows' mammary glands and to assess its influence on the development of piglets. We attempted to assess the endogenic production of vitamin $\mathrm{C}$ contained in sows' colostrum and milk.

\section{Material and methods}

The study was conducted on 60 Zlotnicka White sows and 642 piglets from their litters (366 male piglets and 276 female ones). The sows were in their $3^{\text {rd }}, 4^{\text {th }}, 6^{\text {th }}$ or $7^{\text {th }}$ lactation. There were 15 sows in each lactation group. The study covered a period of one lactation. The sows were fed twice a day with standard total mixed rations, whose composition met their demand according to Feeding Standards (19). The animals were foraged without vitamin $\mathrm{C}$ supplementation. The sows had constant access to water. They were kept in single farrowing crates from about the $7^{\text {th }}$ day before giving birth to the $4^{\text {th }}$ week of lactation. The sows were covered naturally. The offspring came from one father. Labour was constantly supervised by the farm personnel. The piglets underwent standard zootechnical treatments. During the experiment, the piglets received only their mothers' milk. Litters were not standardized during rearing. During labour, each new-born piglet received an ear tag for identification. The sex of the piglets was also identified. Castration was carried out in the first week of life. The following parameters were measured: the piglet's body weight on the $1^{\text {st }}, 7^{\text {th }}$ and $21^{\text {st }}$ day of life $(\mathrm{kg})$, the piglets' mortality between the $1^{\text {st }}$
Tab. 1. Distinction between high and low levels of vitamin C in the sows' colostrum and milk

\begin{tabular}{|c|c|c|}
\hline \multirow{2}{*}{ Lactation } & \multicolumn{2}{|c|}{ Vitamin C concentration levels } \\
& $\begin{array}{c}\text { I } \\
(\mathrm{mg} / 100 \mathrm{ml}) \\
\mathrm{n}=180\end{array}$ & $\begin{array}{c}\text { II } \\
\text { High level } \\
(\mathrm{mg} / 100 \mathrm{ml}) \\
\mathrm{n}=180\end{array}$ \\
\hline $1^{\text {st }}$ day & $\leq 1.10$ & $\geq 1.11$ \\
$7^{\text {th }}$ day & $\leq 0.50$ & $\geq 0.51$ \\
\hline $21^{\text {st }}$ day & $\leq 0.65$ & $\geq 0.66$ \\
\hline
\end{tabular}

and $7^{\text {th }}$ day of life and between the $8^{\text {th }}$ and $21^{\text {st }}$ day of life $(\%)$. The daily growth $(\mathrm{g})$ was measured on each day when the piglets were weighed.

Before sampling of colostrum and milk, the sows had been injected with oxytocin. The content of oxytocin (2-4 ml) depended on the day of lactation, rather than on the sow's weight. Samples of colostrum and milk were collected manually from all active mammary glands on the $1^{\text {st }}$, $7^{\text {th }}$ and $21^{\text {st }}$ day of lactation. On each day of the experiment, two samples of about $7 \mathrm{ml}$ were collected from each sow. Three hundred and sixty samples were analysed in total ( 60 sows $\times 3$ days $\times 2$ samples). All samples were analysed immediately after collection.

The content of vitamin $\mathrm{C}$ was measured according to the methodology invented by Omaye et al. (21) and modified by Markiewicz-Kęszycka et al. (16). In order to determine the influence of vitamin $\mathrm{C}$ on piglet rearing, two concentration levels were distinguished according to the content of vitamin $\mathrm{C}$ in colostrum and milk (Tab. 1).

The data were analysed with the statistical package SAS ${ }^{\circledR}$ V. 9.3 (2014) using multivariate analysis of variance with PROC GLM LSM. The results of calculations were presented as least square means (LSM) and standard errors (SE). Descriptive statistics was used to analyse variables. The results of calculations were expressed as arithmetic means referring to individual traits.

Pearson's phenotypic correlation coefficient between the daily growth of piglets and the content of vitamin $\mathrm{C}$ in the mammary gland secretion was calculated according to the CORR-SAS v. 9.3. procedure (2014).

\section{Results and discussion}

Figure 1 shows the concentration of vitamin $\mathrm{C}$ in the sows' colostrum and milk during 21 days of their lactation. The data show that the content of vitamin $C$ varied during that period. The highest mean concentration, i.e. $1.14 \mathrm{mg} / 100 \mathrm{ml}$, was noted on the $1^{\text {st }}$ day. On the $21^{\text {st }}$ day it decreased to $0.65 \mathrm{mg} / 100 \mathrm{ml}$. During 21 days of lactation, the content of vitamin C decreased by $43 \%$. Csapo et al. (6), Sheng and Fang (24) and Clayes et al. (5) found in their studies that the content of vitamin C amounted to $1.287-8.1 \mathrm{mg} / 100 \mathrm{ml}$ in mare's milk, $2 \mathrm{mg} / 100 \mathrm{ml}$ in donkey's milk, $0.3-2.3 \mathrm{mg} / 100 \mathrm{ml}$ in cow's milk, $0.425-6 \mathrm{mg} / 100 \mathrm{ml}$ in sheep's milk, $0.91-5 \mathrm{mg} / 100 \mathrm{ml}$ in goat's milk, $1-2.54 \mathrm{mg} / 100 \mathrm{ml}$ in buffalo's milk and 2.4-18.4 mg/100 ml in camel's milk. The content of ascorbic acid in human milk amounted 


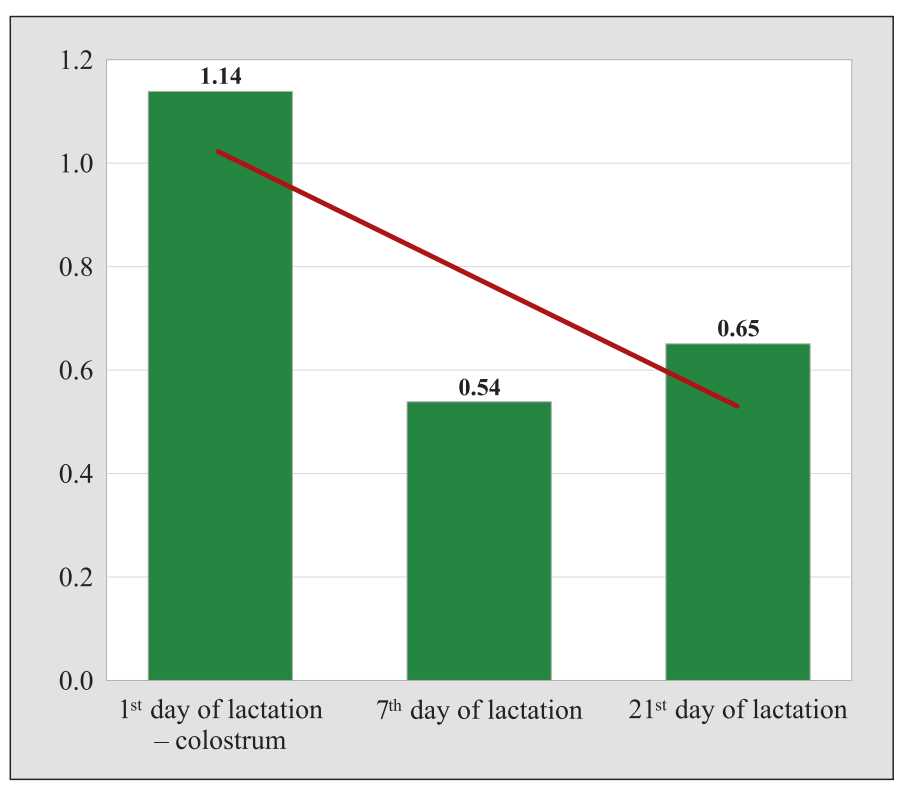

Fig. 1. Concentration of vitamin $C$ in the sows' colostrum and milk (mg/100 ml)

to $0.38 \mathrm{mg} / 100 \mathrm{ml}$. The content of vitamin $\mathrm{C}$ in the sows' milk in our study was similar to that found in cow's, sheep's and goat's milk. Hurley (8) reported that the content of vitamin $\mathrm{C}$ in sow's colostrum ranged from 6.4 to $30.6 \mathrm{mg} / 100 \mathrm{ml}$, whereas the content in milk ranged from 4.5 to $13.0 \mathrm{mg} / 100 \mathrm{ml}$. These values are very different from the results of our study.

Figure 2 shows the relationship between the content of vitamin $\mathrm{C}$ and lactation. The highest content of vitamin C in the sows' colostrum, i.e. $1.29 \mathrm{mg} / 100 \mathrm{ml}$, was observed in animals that lactated for the fourth time. The highest content of vitamin $\mathrm{C}$ in milk, i.e. 0.75 and $0.70 \mathrm{mg} / 100 \mathrm{ml}$, was noted on the $7^{\text {th }}$ and $21^{\text {st }}$ day, respectively, in animals lactating for the sixth time. The
Tab. 2. Influence of the concentration of vitamin $\mathrm{C}$ in the secretion from the sows' mammary glands on the growth of their piglets $(\mathrm{LSM} \pm \mathrm{SE})$

\begin{tabular}{|l|c|c|c|}
\hline \multirow{2}{*}{ Trait } & \multirow{2}{*}{ Days of rearing } & \multicolumn{2}{c|}{ Vitamin C } \\
& & Level I & Level II \\
\hline $\begin{array}{l}\text { Daily growth of piglets } \\
\text { (g) }\end{array}$ & $1-7$ & $116^{\mathrm{A}} \pm 20$ & $184^{\mathrm{B}} \pm 10$ \\
& $8-21$ & $222 \pm 18$ & $243 \pm 14$ \\
& $1-21$ & $169^{\mathrm{a}} \pm 17$ & $214^{\mathrm{b}} \pm 15$ \\
Daily growth of female & $1-7$ & $111^{\mathrm{A}} \pm 20$ & $184^{\mathrm{B}} \pm 21$ \\
piglets (g) & $8-21$ & $230 \pm 20$ & $241 \pm 22$ \\
& $1-21$ & $170^{\mathrm{a}} \pm 21$ & $213^{\mathrm{b}} \pm 12$ \\
\hline $\begin{array}{l}\text { Daily growth of male } \\
\text { piglets (g) }\end{array}$ & $1-7$ & $120^{\mathrm{A}} \pm 19$ & $183^{\mathrm{B}} \pm 13$ \\
& $8-21$ & $213 \pm 14$ & $245 \pm 15$ \\
& $1-21$ & $167^{\mathrm{a}} \pm 12$ & $214^{\mathrm{b}} \pm 11$ \\
\hline
\end{tabular}

Explanation: means with different superscript letters differ significantly at $\mathrm{p} \leq 0.05(\mathrm{a}, \mathrm{b})$ and at $\mathrm{p} \leq 0.01(\mathrm{~A}, \mathrm{~B})$

Tab. 3. Influence of the concentration of vitamin $\mathrm{C}$ in the secretion from the sows' mammary glands on the mortality of their piglets $(\mathrm{LSM} \pm \mathrm{SE})$

\begin{tabular}{|l|c|c|c|}
\hline \multirow{2}{*}{ Trait } & Days of rearing & \multicolumn{2}{c|}{ Vitamin C } \\
& & Level I & Level II \\
\hline $\begin{array}{l}\text { Mortality of piglets } \\
(\%)\end{array}$ & $1-7$ & $7.20 \pm 3.19$ & $6.56 \pm 2.51$ \\
& $8-21$ & $4.96 \pm 2.72$ & $3.37 \pm 1.90$ \\
\hline $\begin{array}{l}\text { Mortality of female } \\
\text { piglets (\%) }\end{array}$ & $1-21$ & $6.00 \pm 2.93$ & $4.97 \pm 2.03$ \\
& $1-7$ & $6.50 \pm 2.94$ & $6.31 \pm 3.20$ \\
\hline $\begin{array}{l}\text { Mortality of male } \\
\text { piglets (\%) }\end{array}$ & $1-21$ & $4.20 \pm 2.75$ & $2.42 \pm 1.08$ \\
& $8-21$ & $5.35 \pm 2.85$ & $4.37 \pm 2.14$ \\
& $1-21$ & $7.90 \pm 3.45$ & $6.80 \pm 2.69$ \\
\hline
\end{tabular}

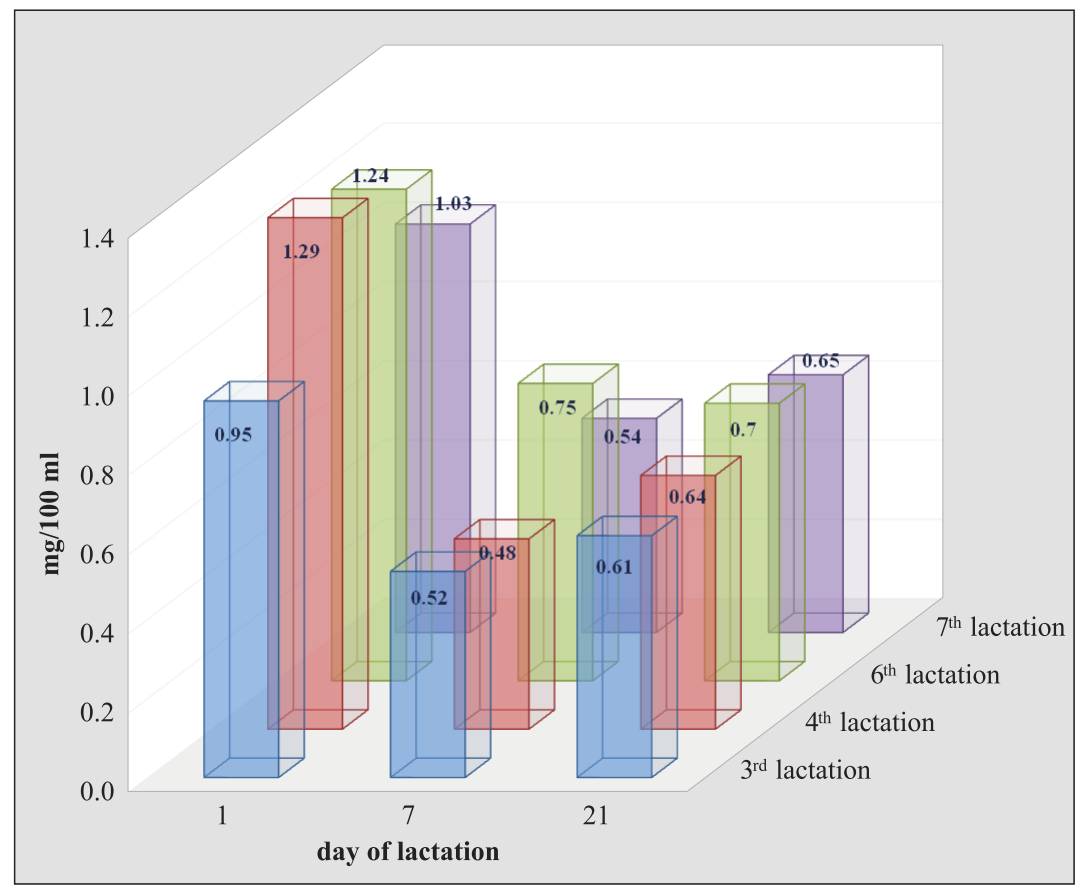

Fig. 2. Content of vitamin $C$ in the sows' colostrum and milk according to their consecutive lactation $(\mathrm{mg} / 100 \mathrm{ml})$ results of our study show that older sows, which had lactated more times, produced more endogenic vitamin $\mathrm{C}$ in their mammary secretions. Table 2 shows the influence of the content of vitamin $\mathrm{C}$ on the growth of piglets. The analysis of the daily growth of all piglets and the growth of the piglets according to their sex shows that the daily growth values were greater if the content of vitamin $\mathrm{C}$ in colostrum and milk collected during rearing was high (level II). On average, the differences amounted to about $45 \mathrm{~g}$, including the sex-dependent differences. These relationships were statistically significant at $\mathrm{P} \leq 0.01$ and $\mathrm{P} \leq 0.05$.

The analysis of the influence of vitamin $\mathrm{C}$ in the secretion from the sows' mammary glands on piglet mortality (Tab. 3) did not reveal any statistically significant differences. Nevertheless, the higher the content of vitamin $\mathrm{C}$ was, the lower the piglet mortality was. The same relationship was observed 
Tab. 4. Coefficient of correlation between the growth of piglets and the concentration of vitamin $C$ in the secretion from the sows' mammary glands

\begin{tabular}{|l|l|l|}
\hline \multirow{2}{*}{ Trait } & \multicolumn{2}{|c|}{ Vitamin C } \\
& Level I & Level II \\
\hline Daily growth of piglets $1^{\text {st }} 7^{\text {th }}$ day (g) & 0.4930 & $0.7551^{* *}$ \\
\hline Daily growth of piglets $8^{\text {th }}-21^{\text {st }}$ day (g) & 0.2217 & 0.3350 \\
\hline Daily growth of piglets $1^{\text {st }}-21^{\text {st }}$ day (g) & $0.5099^{*}$ & $0.7919^{* *}$ \\
\hline
\end{tabular}

Explanations: $*-\mathrm{p} \leq 0.05 ; * *-\mathrm{p} \leq 0.01$

when the piglets were divided according to their sex. Nowaczewski and Kontecka (20) studied poultry and observed that the mortality of the birds decreased by $7.3 \%$ when the feed contained more vitamin C.

Table 4 shows the correlation between the daily growth of piglets and the content of vitamin $\mathrm{C}$ in the secretion from the mammary glands. The dependencies between the traits were positively correlated at $\mathrm{P} \leq 0.01$ and $\mathrm{P} \leq 0.05$. The correlations showed a strong relationship between the traits. When the content of ascorbic acid was high (level II), the coefficient of correlation amounted to $\mathrm{r}=0.7551^{* *}$ for the growth of piglets during the first week of their lives and $r=0.7919^{* *}$ for the growth of piglets during the entire rearing period.

A study by Lechowski (11) confirmed the positive influence of vitamin $\mathrm{C}$ on the rearing of piglets, as it decreased their mortality and increased their growth. The author also observed that the female reproductive organs became enlarged, and the number of ovarian follicles and corpora lutea increased. Progesterone and oestradiol levels in the blood of sows were also elevated. When sows that were pregnant for the first time and received feed with vitamin $\mathrm{C}$ gave birth, their colostrum and milk contained more dry mass, protein, immunoglobulin $\mathrm{G}$ and vitamin $\mathrm{C}$.

The results of a study by Kawęcka et al. (10) were different from the findings of our study. Those authors studied how vitamins $\mathrm{E}$ and $\mathrm{C}$, added to feed for sows which had produced large numbers of piglets, influenced further reproductive capacity of the sows and the parameters of their offspring. The feed given to the sows in that experiment was supplemented with ascorbic acid at a dose of $500 \mathrm{mg} / \mathrm{kg}$. The experiment did not reveal any positive influence of supplementation on piglet rearing. Piglets born from the sows in the experiment had lower body weights after weaning. It may have been caused by a negative influence of large doses of vitamin $\mathrm{C}$ on lactation. As pigs are capable of synthesising vitamin $\mathrm{C}$ from glucose in their organisms, their condition improves, which has positive influence on the quality of meat and offal $(12,13)$. Colostrum and milk significantly influence the immunity of piglets (23). Ascorbic acid affects immune processes in the organism (7) by stimulating the activity and migration of granulocytes, monocytes, macrophages and lymphocytes and by participating in the production of immunoglobulins $(1,22)$.

Vitamin $\mathrm{C}$ has positive influence on animals, especially those exposed to stress. Its role as a mitigating factor is to participate in the synthesis of adrenaline and noradrenaline and to protect adrenaline from oxidation. The concentration of vitamin $\mathrm{C}$ in the pituitary gland and adrenal cortex is several times greater and decreases considerably under heavy stress (15).

The findings of our study show the importance of endogenic production of vitamin $\mathrm{C}$ in sows' colostrum and milk and its bioactivity. The higher concentration of vitamin $\mathrm{C}$ produced better rearing effects in the form of a faster growth of piglets and their lower mortality. Although the diet of the sows was not supplemented with ascorbic acid, the research proved the importance of this compound.

\section{References}

1. Anderson R.: Ascorbic acid and immune actions. Mechanism of immunostimulation. Vitamin C. Counsell. London 1981, 1, 249-253.

2. Bendich A., Machlin L. J., Scandurra O., Burton G. W., Wayner D. D. M.: The antioxidant role of vitamin C. Adv. Free Radical Bio. 1986, 2, 419-444.

3. Chatterjee I. B.: Evolution and the biosynthesis of ascorbic acid. Science 1973 , 182, 1271-1272.

4. Chatterjee I. B., Majumder A. K., Nandi B. K., Subramanian N.: Synthesis and some major functions of vitamin $\mathrm{C}$ in animals. Annals New York Academy of Sciences $1975,258,24-47$.

5. Claeys W. L., Verraes C., Cardoen S., Block de J., Huyghebaert A., Raes K., Dewettinck K., Herman L.: Consumption of raw or heated milk from different species: An evaluation of the nutritional and potential health benefits. Food Control 2014, 42, 188-201.

6. Csapó J., Martin T. G., Csapó-Kiss Z. S., Házas Z.: Protein, fats, vitamin and mineral concentrations in porcine colostrum and milk from parturition 60 days. Int. Dairy J. 1996, 6, 881-902.

7.Ettinger S. J., Feldman E. C.: Textbook of Veterinary Internal Medicine. W. B. Saunders Company, Philadelphia 1995.

8. Farmer Ch.: The gestating and lactating sow, [in:] Hurley W. L.: Composition of sow colostrum and milk. Wageningen Academic Publisher 2015, 9, 193-230.

9. Janda K., Kasprzak M., Wolska J.: Vitamin C - structure, properties, occurrence and functions. Pom. J. Life Sci. 2015, 61, 419-425.

10. Kawęcka M., Sosnowska A., Jacyno E., Kołodziej A., Matysiak B., Kamyczek M.: Wpływ dodatku witamin E i C w żywieniu loch na ich użytkowość i odchów prosiąt. Przegl. Hodowlany 2013, 81, 9-11.

11. Lechowski J.: Ocena efektywności dodatku kwasu askorbinowego do paszy na cechy reprodukcyjne młodych loszek i knurów inseminacyjnych oraz właściwości fizyczne i chemiczne mięsa tuczników. Rozprawy Naukowe Uniwersytetu Przyrodniczego w Lublinie 2009, 334, 1-79.

12. Lechowski J., Nagórna-Stasiak B., Kowalczyk M.: Synteza witaminy C u kurcząt w dwóch pierwszych miesiącach życia. Med. Weter. 1998a, 54, 181-184.

13. Lechowski J., Nagórna-Stasiak B., Kowalczyk M.: Synteza witaminy C w mięśniach szkieletowych i ścianie przewodu pokarmowego u kurcząt. Ann. UMCS, ser. DD, 1998b, 53, 117-123.

14. Maćkowiak K., Torliński L.: Contemporary view on the role of vitamin C in human physiology and pathology. Nowiny Lekarskie 2007, 76, 349-356.

15. Madej E., Grzęda M.: Właściwości, niedobór i zakres zastosowań witaminy C w lecznictwie zwierząt. Med. Weter. 2000, 56, 627-631.

16. Markiewicz-Kęszycka M., Czyżak-Runowska G., Wójtowski J., Jóźwik A., Pankiewicz R., Eęska B., Krzyżewski J., Strzałkowska N., Marchewka J., Bagnicka E.: Influence of stage of lactation and year season on composition of mares' colostrum and milk and method and time of storage on vitamin C content in mares' milk. J. Sci. Food Agric. 2015, 95, 11, 2279-2286.

17. Min Y. N., Niu Z. Y., Sun T. T., Wang Z. P., Jiao P. X., Zi B. B., Chen P. P., Tian D. L., Liu F. Z.: Vitamin $\mathrm{E}$ and $\mathrm{C}$ supplementation improves antioxidant status and immune function in oxidative-stressed breeder roosters by up-regulating expression of GSH-Px gene. Poultry Sci. 2018, 97, 1238-1244. 
18. Moszczyński P., Pyć R: Biochemia witamin. Witaminy lipofilne i kwas askorbinowy. Część II. PWN. Warszawa 1999, 112-136.

19. Normy żywienia świń. Zalecenia żywieniowe i wartość pokarmowa pasz dla świń. 2014, 1-94.

20. Nowaczewski S., Kontecka H.: Znaczenie witaminy C w żywieniu drobiu. Pol. Drob. 2000, 10, 10-11.

21. Omaye S. T., Turnbull J. D., Sauberlich H. E.: Selected methods for the determination of ascorbic acid in animal cells, tissues and fluids. Methods Enzymol. 1979, 62, 3-11.

22. Pinelli-Saavedra A., Calderón de la Barca A. M., Hernández J., Valenzuela R., Scaife J. R.: Effect of supplementing sows' feed with $\alpha$-tocopherol acetate and vitamin $C$ on transfer of $\alpha$-tocopherol to piglet tissues, colostrum and milk: Aspects of immune status of piglets. Res. Vet. Sci. 2008, 85, 1, 92-100.

23. Salmon H.: The mammary gland and neonate mucosal immunity. Vet. Immunol. Immunopathol. 1999, 72, 143-155.
24. Sheng $Q$., Fang X.: Bioactive components in mare milk, [in:] Park Y. W., Bioactive Components in Milk and Dairy Products. Wiley-Blackwel Oxford 2009, 195-213.

25. Wernicki A., Stachura R., Hola P., Puchalski A., Dec M., Stęgiersk D., ŻurekA., Urban-Chmiel R.: Efficacy of florfenicol and flunixin followed with vitamin E and/or $\mathrm{C}$ on selected oxidative and inflammatory mechanisms in young cattle under transport and adaptation stress. Med. Weter. 2018, 74, 266-271.

26. Włodek L.: Reaktywne formy tlenu (RFT) w warunkach fizjologicznych i patologicznych. Komórkowe systemy antyoksydacyjne. Farmakol. Pol. 2004, 60, 404-419.

27. Zhang P. Y., Xu X., Li X. C.: Cardiovascular diseases: oxidative damage and antioxidant protection. Eur. Rev. Med. Pharmacol. Sci. 2014, 18, 3091-3096.

Corresponding author: Prof. Marek Babicz, Akademicka 13, 20-950 Lublin, Poland; e-mail: marek.babicz@up.lublin.pl 